\title{
Role of experts and public participation in pollution control: the case of Itai-itai disease in Japan ${ }^{1}$
}

\author{
Masanori Kaji \\ Graduate School of Decision Science and Technology, Group of History of Science and Technology, \\ Tokyo Institute of Technology, W9-79, 2-12-1 Ookayama, Meguro-ku, Tokyo 152-8552, Japan
}

\begin{abstract}
Itai-itai disease was first noticed in the Junzu River basin region in Toyama prefecture in central Japan around the 1930s. However, it was not identified as a cadmium poisoning disease until the 1960s. A local physician, with cooperation from outside experts, confirmed that the disease was caused by pollution from the Kamioka mine (owned by the Mitsui Mining \& Smelting Company Ltd) located in the upstream region of the river. In the mid-1960s, the victims of Itai-itai disease filed a suit against the company and won their case in 1972. The victims received compensation and signed a pollution control agreement with the company. The case of Itai-itai disease is a rare example of successful pollution control in Japan: the annual inspections of the ensuing 40 $\mathrm{yr}$, based on the pollution control agreement, show a reduction of cadmium concentrations in the river to natural levels. By analyzing the roles of various experts involved, this case study has contributed substantially to an understanding of the nature of expertise and the significance of public participation in the resolution of environmental problems.
\end{abstract}

KEY WORDS: Itai-itai disease Pollution control $\cdot$ Cadmium $\cdot$ Public participation $\cdot$ Victims Mining pollution

\section{INTRODUCTION}

During the 1960s and 1970s, Japan enjoyed a period of very high economic growth but suffered at the same time from various forms of pollution, such as air, water, noise, and mining pollution. Japan was even referred to as 'one of the advanced nations of the world in pollution'? . Pollution-related diseases became a matter of public concern.

Itai-itai disease was one of these diseases, caused by a very severe type of cadmium poisoning resulting

\footnotetext{
1The present publication is a revised and expanded version, published in English with permission of the copyright holder, of papers in Japanese by Kaji $(2005,2009)$

${ }^{2}$ In his special message on the environment to the US Congress on 10 February 1970, USA President Richard Nixon implicitly criticized Japan as being the most polluted country in the world (see Hashimoto 1988, p. 158)
}

from the pollution of rice fields. The liquid wastes of the Kamioka mine, owned by the Mitsui Mining \& Smelting Company Ltd (Mitsui Kinzoku), were eventually incriminated as the source of the cadmium. Kamioka was one of the richest zinc mines in Japan. Cadmium occurs as a minor component in most zinc ores and therefore is a byproduct of zinc production ${ }^{3}$. The numbers of patients suffering from this disease between 1910 and 2007 were estimated at $\sim 400$

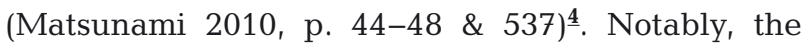
majority of the patients were women ${ }^{5}$, likely because

\footnotetext{
${ }^{3}$ Cadmium is located just below zinc in the periodic table, and its properties are similar to those of zinc. Most cadmium in nature occurs as atomic substitution for zinc in zinc minerals, and it is produced as an associate product when zinc ores are reduced. www.mii.org/Minerals/photocad. html (accessed 17 November 2011), Daintith (2008, p. 91)
} 
women generally have lower body weight and less dense bone mass, and their physiology specifically enhances the uptake of cadmium and therefore its damage (Matsunami 2010, p. 451-461).

The affected residents sued polluters in an attempt to complain publicly and receive compensation for damages. This attempt was included in the so-called 'four major pollution-related lawsuits' of the 1970s: Itai-itai disease, Minamata disease, the Second Minamata disease in Niigata prefecture, and Yokkaichi pollution ${ }^{6}$. All of the victims, including those of Itai-itai disease, filed a suit against the companies that caused the damages and won their cases. However, only in the case of Itai-itai disease did victims succeed in forcing almost complete pollution control, which was rare in Japan at the time.

The case of Itai-itai disease will shed light on problems with expertise and public participation, especially on the role of experts and the significance of public participation in resolving techno-environmental problems ${ }^{\mathbf{7}}$.

\section{KAMIOKA MINE AND MINING POLLUTION}

The Toyama basin, located in central Honshu (Japan's main island), has been one of the richest rice producing areas since the Middle Ages, and the Jinzu River is one of the 2 main rivers running through this basin (the other is Sho River) (Fig. 1). The Kamioka mine, which is located in the upstream region of the Jinzu River, was first developed in the 17 th century as a silver, copper, and lead mine (Fig. 2).

After the Meiji Restoration in 1868, which marked the beginning of the westernization of Japan, the Kamioka mine was purchased by the Mitsui Com-

\footnotetext{
${ }^{4}$ Matsunami (2010) is the most comprehensive and readable book that analyzes every aspect of Itai-itai disease and related cadmium poisoning in Japan. Matsunami (2010, p. 453) lists 195 officially designated victims of Itai-itai disease between 1967 and 2008 and states that 200 victims must have died before 1967, when the official system of certification of victims was initiated

$\underline{5}$ There were only 3 male victims $(1.5 \%)$ out of 195 victims officially designated between 1967 and 2008 (Matsunami 2010, p. 453)

${ }^{6}$ See section 1 in chapter 2 in Kankyo-cho (1973). The section describes each lawsuit and emphasizes the importance of anti-pollution measures by private companies in industry in Japan

${ }^{7}$ For a good introduction to the recent literature on expertise and public participation, see, for example, Evans \& Collins (2008) and Sismondo (2010, p. 180-188)
}

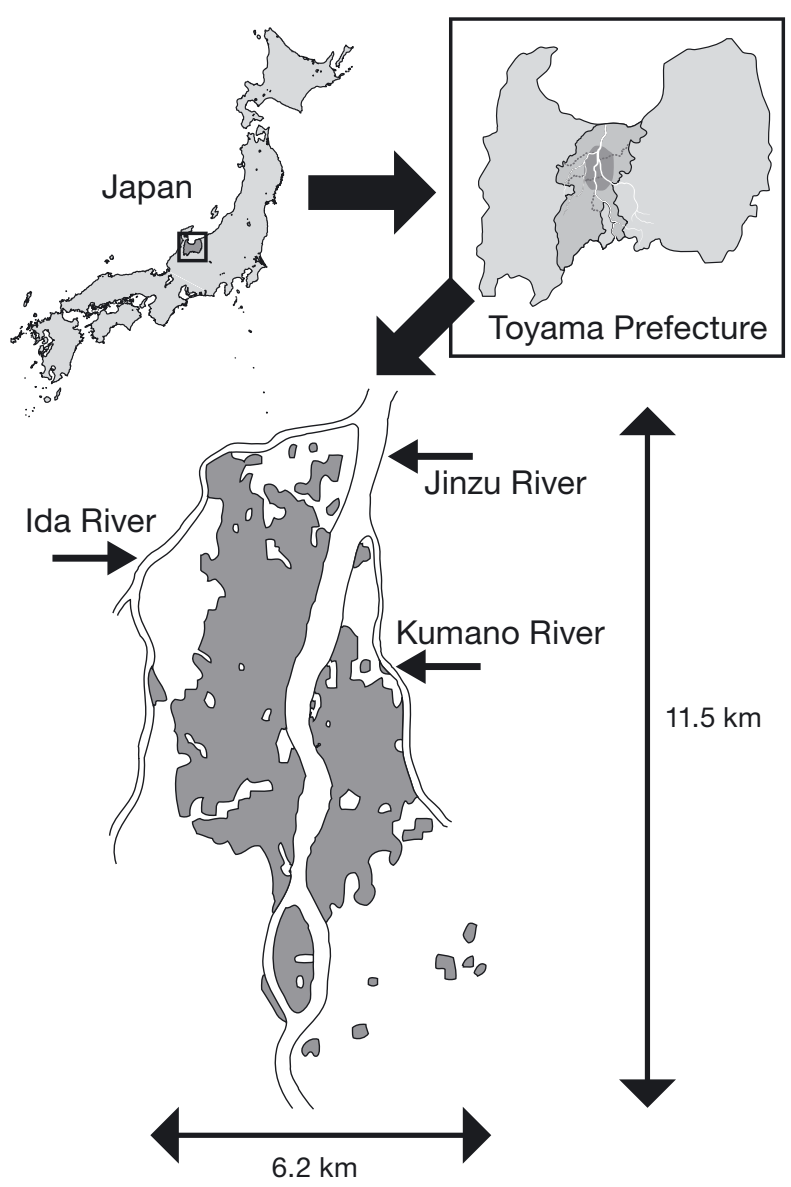

Location of polluted area

Fig. 1. A map of the polluted area in the Jinzu river basin of the Toyama Plain (Redrawn from Iwamoto 1999, with permission from the author's group)

pany (hereafter Mitsui) ${ }^{\mathbf{g}}$, one of the largest private capital groups. By 1889, Mitsui had purchased all of the pits and operation rights of the Kamioka mine. In 1905, Mitsui started to mine zinc in Kamioka. At first, Japan exported zinc ore and imported zinc metal because the country had no smelting facilities. Zinc ore was initially separated based on density differences, but in 1909 zinc minerals began to be separated using surfactants and wetting agents (froth flotation). In 1914, in Miike, Fukuoka prefecture, Mitsui introduced zinc ore smelting processes to pro-

\footnotetext{
${ }^{8}$ The Mitsui family, a merchant family in the 17 th century, established the Mitsui Company in 1872 after the Meiji Restoration, and in 1876 the company was reorganized into Mitsui Bank, Japan's first private bank, and Mitsui Bussan, a trading company. These 2 companies, together with Mitsui Mining, established in 1888, became the core enterprises of one of the largest corporate conglomerates (zaibatsu) in modern Japan
} 


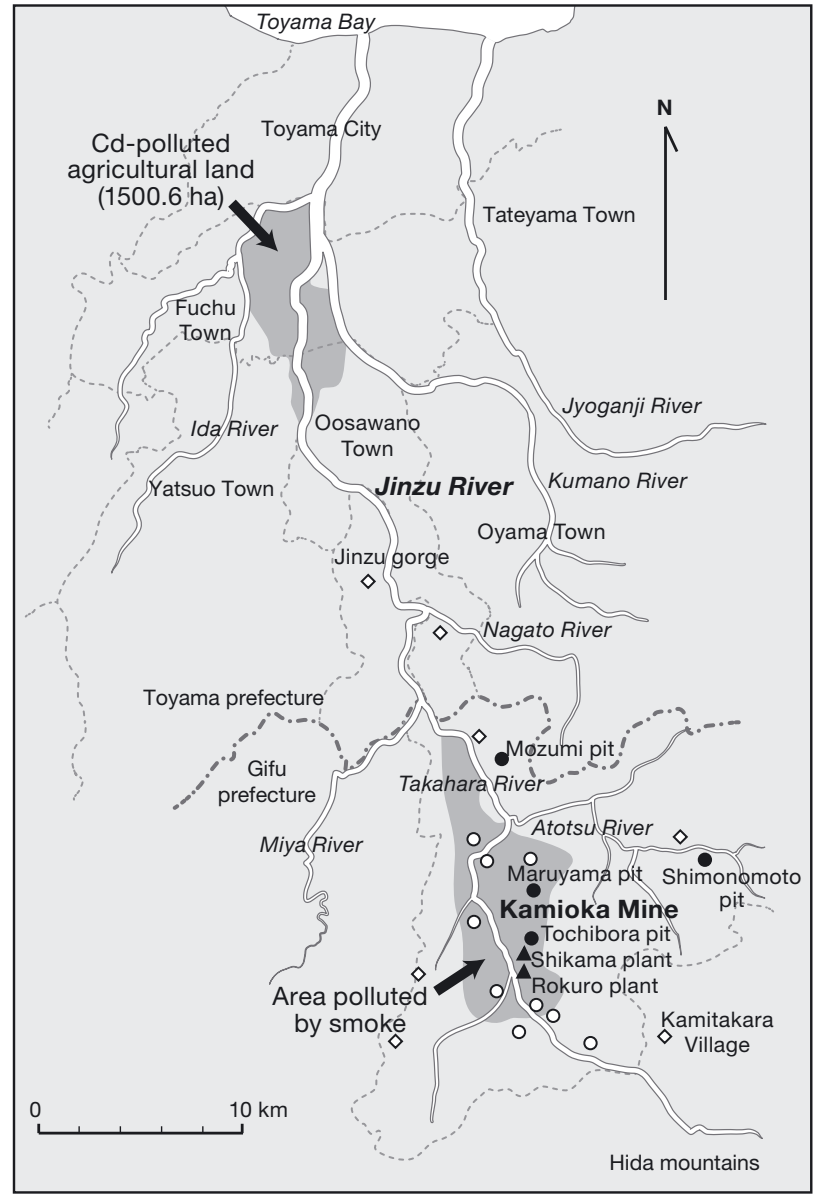

Fig. 2. The Jinzu River Basin and the location of the Kamioka mine (Redrawn from Kurachi 1999, with slight modification and with permission from the author)

duce zinc metal, the first in Japan ${ }^{9}$. In the 1920s, after World War $\mathrm{I}^{\mathbf{1 0}}$, the Kamioka mine became one of the largest zinc producers in Japan ${ }^{11}$. Newly introduced, improved froth flotation processes in the 1920s helped to increase zinc production, but some of the finely powdered mineral particles produced during the frothing process escaped and floated down the river. These fine particles were then easily oxidized

\footnotetext{
${ }^{9}$ Smelters in Kamioka started to operate in 1943 (Matsunami 2010, p. 88)

10 Japan took advantage of the absence of European powers in Asia, due to the war, to expand its influence in Asia and in the Pacific. It enjoyed an economic boom and unprecedented prosperity, and the years between 1910 and the 1920s marked a turning point for the Japanese economy 11Mitsui produced $\sim 48 \%$ of Japan's zinc metal after 1925 (Matsunami 2010, p. 88). The Kamioka mine produced $57 \%$ of the zinc ore mined in Japan in the first 6 mo of 1950 (Yamada 1951, p. 46)
}

into ions, which were, in turn, readily absorbed by plants and humans (Kurachi et al. 1979, p. 81). The waste from the Kamioka mine increased sharply during the 1930s, when the war with China created a significant demand for zinc production. Farmers and peasants who used the water of the Jinzu River for agriculture and fishermen who fished those same waters noticed decreases of crop yields and catch of fish and established an association for fighting against mining pollution in 1932. During World War II, unskilled workers replaced skilled miners, who had been drafted. The result was an increase in yield loss along with an increased volume of unnecessary waste, which was dumped into the Jinzu River. Agricultural damage in terms of rice production and damage to the fishery industry noticeably increased.

Cadmium-containing ores are rare in nature, with greenocite (CdS) being the only major cadmium mineral. This mineral is almost always associated with sphalerite (ZnS), the main zinc ore in Kamioka. Thus, cadmium was a common by-product of zinc ore mining. During World War II, cadmium had no industrial value $\frac{12}{}$, so Mitsui simply discarded it as waste into the Jinzu River. Mitsui began to extract cadmium as part of the zinc production process in the Kamioka mine only after 1948.

\section{DISCOVERY OF ITAI-ITAI DISEASE AND ITS CAUSES}

Although Itai-itai disease was named and identified in the 1950s, the Ministry of Health and Welfare estimated in 1968 that the first patients of the disease appeared as early as the 1910s in the area of the Jinzu River basin in Toyama prefecture ${ }^{\mathbf{1 3}}$. Shigejiro Hagino, a local physician, was one of the first to notice this unfamiliar disease, characterized by severe pain throughout the body, around 1935 and correctly predicted mining pollution as its cause. The Hagino family was one of the prestigious and influential local landholders, and for generations, the

\footnotetext{
12The first cadmium production for industrial use in Japan began in 1929. Cadmium was first used for pigments and as a component for low melting alloys. Today, cadmium is used mainly in batteries (especially Ni-Cd batteries) (Matsunami 2010, p. 126-128)

$\underline{13}$ This estimation was provided in the announcement by the Ministry of Health and Welfare on 8 May 1968 (see 'Central and local administrations on Itai-itai disease'). Matsunami also confirmed this estimate (Matsunami 2010, p. 40-48)
} 
family members had been physicians (Hatta 1983, p. 22). Noboru Hagino (1915-1990), Shigejiro's son, served in the army as a doctor soon after graduating in 1940 from the Kanazawa Medical College (now the Medical School of the Kanazawa University), a national medical college not far from Toyama. He returned to his home village in March 1946 from China, where he had served as an army doctor. He inherited a local clinic from his father, who had passed away in 1943.

Soon after World War II, Itai-itai disease, initially thought to be a rheumatic disease with no connection with mining waste, was reported in a medical journal by researchers at the Kanazawa Medical College (Matsunami 2010, p. 9-11). The 44 patients studied had an average age of $57.7 \mathrm{yr}$ and were mostly women. A more thorough medical study of the disease was conducted by a group of doctors from a rheumatology institute in Tokyo in 1955. Noboru Hagino participated in this study as a local doctor, unaware of his father's earlier observations and not anticipating any connection with wastes from the mine (Matsunami 2010, p. 11-14). The Toyama Shinbun, a local newspaper, gave the syndrome its name of Itai-itai disease $\underline{14}$ because it was a very painful disease, and patients, mostly women over 35 years old, often cried out in pain, 'Itai, itai' (meaning 'it hurts, it hurts'). The study concluded that this disease was not rheumatic but was a kind of osteomalacia (Matsunami 2010, p. 13-14).

Nobuo Hagino, like other physicians, first thought that overwork and malnutrition were the cause of disease, but he soon realized that all of the patients lived and worked near the midstream region of the Jinzu River, in an area irrigated by river water. Therefore, Hagino began to consider mining pollution from the Kamioka mine, located upstream, as a potential cause. In 1957, Hagino reported to an academic society that the cause of the disease was heavy metals, especially zinc. His report was heavily criticized by other researchers, who still believed that the disease was caused by malnutrition, overwork, and lack of sunshine during the winter. They did not believe that there was sufficient evidence for mining pollution as a possible cause of the illness. Hagino himself also considered zinc, not cadmium, to be the cause of the disease at this stage of his research. Kin-

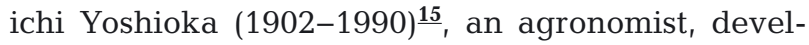
oped Hagino's hypothesis into well-founded argu-

${ }^{14}$ Toyama Shinbun, 4 August 1955. See also the photo reproduction of the article in Matsunami's book (Matsunami 2010, p. 10) ments and proposed that cadmium was the causative agent of the disease.

In 1948, 2 organizations with the same name, the Jinzu Mining Pollution Prevention Council (JMPPC), were established, one led by heads of local administrations and the other led by heads of agriculture cooperatives. There is a history of conflict between groups of farmers and fishermen and large mining companies from the early 20th century in various parts of Japan $\underline{16}$. It was not unusual for companies to pay compensation to the complaining groups in the damaged areas. The owners of the Kamioka mine paid money to complaining groups every year from 1949 to 1954 after negotiation (Matsunami 2010, p. 153-154). In the meantime, the 2 councils merged in 1951, and the new organization demanded compensation from the Kamioka mine. In 1955, the 3 parties (the JMPPC, Toyama Prefecture, and the Kamioka mine) concluded an agreement on the amount of compensation, which was to be revised every $5 \mathrm{yr}^{\underline{17}}$. In 1960, the next compensation agreement was concluded, with less money being issued. The Fuchumachi branch of the JMPPC decided to commission Kin-ichi Yoshioka to conduct research on the damages caused by mining pollution. The aim was to find stronger evidence against the Kamioka mine, which had tried to reduce compensation to the victims in every possible way. Yoshioka was a well-known expert on agricultural flood damage, and in September 1958 he happened to visit the Jinzu River to conduct research on flood damage and on agricultural damage caused by mining pollution. In August 1960, the Fuchu-machi branch of the JMPPC commissioned him to complete a full survey of the agricultural damage.

\footnotetext{
${ }^{15}$ Kin-ichi Yoshioka was born in Okayama prefecture. He graduated from the Agricultural Department of Kyoto Imperial University. After working at the Science of Labor Institute at Kurashiki and Ohara Agricultural Institute, both located in Okayama prefecture, he became a professor at Doho University, a private university in Nagoya, and then at Okayama College of Science. Later, he became president of the Kanazawa University of Economics in Kanazawa

${ }^{16}$ Shozo Tanaka (1841-1913) was one of the first leaders in such conflicts. He was a statesman and a member of the House of Representatives of Japan, and was famous as a leader of a protest movement against the Ashio Copper Mine in Tochigi Prefecture, which caused agricultural and fishery damage in the area downstream. See, for example, Yui (1984) and Dehn (1995)

${ }^{17}$ The compensation money was only for the agricultural and fishery damages, not for the pollution-related disease. The connection between Itai-itai disease and mining pollution was beginning to be noticed in the mid-1950s and was proved in the early 1960 s
} 
Yoshioka extended his study of agricultural damage to include other forms of possible biological damage, including Itai-itai disease, which at that time was still a local disease of unknown cause. Using an epidemiological study, he plotted the locations of known Itaiitai disease patients on a map, with the help of Hagino. He clearly demonstrated that the disease appeared in those places irrigated by the Jinzu River. His analysis of the metal content of water, soil, vegetables, animals, and the organs of the patients revealed an unusual abundance of cadmium. He noticed a correlation between the annual increase in numbers of patients and the increased production of zinc ore at the Kamioka mine. He also found a similar case of chronic cadmium poisoning in a French medical journal (Nicaud et al. 1942). In June 1961, in his report to the head of the Fuchu-machi branch of the JMPPC, Yoshioka concluded that the cause of Itai-itai disease was cadmium discarded by the Kamioka mine (Yoshioka 1961) ${ }^{\mathbf{1 8}}$. At the same time, he reported these results, together with Hagino, at a scientific meeting of a medical society (Matsunami 2010, p. 28-29).

Professor Jun Kobayashi (1909-2001) ${ }^{19}$, an analytical chemist at Okayama University, helped with the detection of cadmium in the samples sent by Yoshioka and Hagino. He developed specific heavy metal analysis techniques to advance the study of Itai-itai disease. These 3 experts, with their different backgrounds, played a decisive role in identifying the cause of Itai-itai disease.

\section{CENTRAL AND LOCAL ADMINISTRATIONS ON ITAI-ITAI DISEASE}

The central government and local authorities were not very cooperative in their responses to the victims of Itai-itai disease. At the end of 1961, Toyama prefecture set up a Special Committee for Prevention of Local Diseases, the first of this kind on Itai-itai disease by a local authority. The committee made a list of patients and surveyed them using questionnaires to reinforce the malnutrition theory of the disease

\footnotetext{
$\underline{18}$ Yoshioka later published the conclusion in a local medical journal (Yoshioka 1964)

19 Jun Kobayashi was born in Kurashiki, Okayama prefecture. He graduated from the Agricultural Department of Tokyo Imperial University. After working at agricultural experimental stations of the Ministry of Agriculture and Forestry, he worked as research associate at Ohara Agricultural Institute. After World War II, he became a faculty member of Okayama University, a national university in Okayama prefecture. He retired in 1975
}

and to defuse the idea that mining pollution was the cause of the disease. The Toyama prefecture administration was trying to promote industrialization in the middle of the Junzu River Basin of the Toyama Plain in the late 1950s. They feared that the emergence of a pollution-related disease, like Itai-itai disease, would deter enterprises from coming to the region (Matsunami 2010, p. 30-32).

In 1963, government-funded research groups were established under the auspices of the Ministry of Health and Welfare and the Ministry of Education to look into the matter. In January 1967, the joint research group of both ministries admitted that cadmium was one of the causes of the disease but claimed that other reasons might also exist (Matsunami 2010, p. 32-35). Victims were disappointed by this unclear conclusion by the governmental research groups, and in March 1968, they decided to file a case against Mitsui and the government.

During this period the Ministry of Health and Welfare was beginning to realize the need for a new approach to industrialization and urbanization in Japan. When the pollution department was created in the ministry in April 1964, Michio Hashimoto (19242008) was appointed as its first head of department $\underline{\mathbf{2 0}}$. Hashimoto belonged to the first generation that was aware of new approaches in public health and he played a key role in changing the ministry's attitude. The ministry commissioned further study to the Japan Public Health Association (JPHA), the oldest non-governmental public health organization in Japan, to investigate the aspects which the joint research group of 2 ministries did not cover. In the spring of 1967, a group of researchers organized by JPHA - which included professors of Kanazawa University, researchers from Toyama and Jun Kobayashi from Okayama (see the previous section) — showed a correlation between the appearance of patients with Itai itai disease and the use of the Jinzu River water,

\footnotetext{
${ }^{20}$ This is Hashimoto's autobiographical reminiscence. He was born in Osaka in 1924. He graduated in 1948 from the Medical School of Osaka University and worked as doctor in the Public Health Center of the Osaka Prefecture. He was first sent to study at the National Institute of Public Health of the Ministry of Health and Welfare in Tokyo for $1 \mathrm{yr}$, and in 1954, he was sent to the United States for $1 \mathrm{yr}$ to study public hygiene (a Master's course) at the Harvard School of Public Health. After returning to Japan, he was recruited in 1957 by the Department of Public Health of the Ministry of Health and Welfare. In 1972, he moved to the Environment Agency, established in the previous year. After an early retirement in 1978, he became professor of Public Health at Tsukuba University, which was a newly established national university. See Hashimoto (1988)
} 
as well as the degree of cadmium pollution in the soil (Matsunami 2011, p. 75-77).

Hashimoto insisted that the government should act based on available scientific evidence and should not wait for conclusive scientific proof, to avoid a belated decision (Hashimoto 1988, p. 136) ${ }^{21}$. His opinion was accepted by the ministry. Based on the results of various investigations, on 8 May 1968, the Minister of Health and Welfare at the time, Sunao Sonoda (1913-1984), announced that the disease was caused by cadmium poisoning, and the only possible source of the cadmium was the effluent coming from the Kamioka mine.

\section{RESIDENT MOVEMENT AND THE ITAI-ITAI DISEASE TRIALS}

Mining damage to agriculture occurred much earlier than human health damage with what became visible as Itai-itai disease. As early as 1890, sulfur dioxide gas from roasting furnaces (used to reduce sulfur content and heavy metal powder dust) caused damage in the area surrounding the Kamioka mine. From 1896, agricultural and fishery damage became a problem in the midstream and downstream areas of the Jinzu River. Around 1932, the Jinzu River Mining Pollution Prevention Union was established, and the Union asked the prefectural administration to analyze the river water and demanded that Mitsui Mining \& Smelting Comany Ltd build preventive facilities (Kurachi et al. 1979, p. 109-111).

The JMPPC was established to counter the pollution in the villages in the downstream area of the Jinzu River. Although the Council paid attention to agricultural damages, it did not look at pollution effects on humans (Fujikawa 2005, p. 108-110).

After Hagino and Yoshioka reported at a 1961 academic meeting that the cause of Itai-itai disease, based on well-founded research, was cadmium discarded by the Kamioka mine, a number of research groups were established by the prefecture and the central government. The locals, including Hagino,

\footnotetext{
$\underline{21}$ Hashimoto referred to the case of the Minamata disease as such a belated decision (Hashimoto 1988, p. 145). This was one of the earliest announcements in Japan by government officials based on what later became known as precautionary principles

$\underline{22}$ Hagino was much criticized and was under pressure not to work on Itai-itai disease. He once almost gave up studying the disease, and he traveled to the United States and Europe to escape the embattled situation during 1963 and 1964 (Matsunami 2010, p. 158-159)
}

expected a rightful solution by the authorities ${ }^{22}$. However, the joint research groups of the Ministry of Health and Welfare and the Ministry of Education presented inconclusive evidence and mentioned the possibility of cadmium as the cause of the disease only in passing. This disappointed the patients, who expected conclusive results from governmental research. Young local leaders in the polluted areas, together with Hagino, realized that they had to act themselves to solve the problem. In November 1966, the Itai-itai Disease Residents' Association was established in the Kumano District of Fuchu-machi, Toyama prefecture, which was the most polluted area, with a high concentration of patients. The aims of the Residents' Association were to obtain patient relief, free water supply, remediation of polluted soil, and clarification of the company's responsibility for the disease (Matsunami 2010, p. 162-171). The members of the association tried to negotiate directly with the Kamioka mine several times in the summer of 1967 on the issue of compensation for dumping the polluted effluent, but the company denied the charge, stating that there was no scientific proof of any causal relationship between the company's activity and the disease. A representative of the Kamioka mine even said that the company would willingly compensate every incident of damage if official institutions verified any responsibility of the 'world-renowned large' company, Mitsui, for the disease (Itai-itai byo sosho bengo-dan 1972, p. 585; Matsunami 2010, p. 171-172).

In the 1960s, several acute cases of pollution-related disease appeared in Japan and attracted nationwide attention. Minamata disease, a neurological syndrome caused by severe mercury poisoning, was the most famous. The disease was first discovered in Minamata City, in Kumamoto prefecture in Southern Japan, in 1956. It was caused by methyl mercury found in the industrial waste from the Chisso Corporation's chemical factory in Minamata. In June 1965, patients with a similar mercury poisoning disease were found in Niigata prefecture, a neighboring prefecture to the Toyama prefecture, and this was referred to as the second Minamata disease. Its victims and residents organized a victims' association in August of the same year because they were unhappy with the belated action of the government. The association filed a suit against Showa Denko, the responsible company, in June 1967, as the first of 4 major pollution-related lawsuits ${ }^{23}$. Several members of the Itai-itai Disease Residents' Association participated in the site inspection for the lawsuit in October 1967 and identified the need for a lawsuit. 
At the end of 1967, the Itai-itai Disease Residents' Association held a meeting in Fuchu-machi to discuss a lawsuit, and 2 young lawyers from Toyama prefecture, Tatsuru Shimabayashi and Jun-ichi Matsunami, came to the meeting $\underline{\underline{24}}$. After vacillating for some time, the Residents' Association, with the help of these young lawyers, decided to file a lawsuit against Mitsui in January 1968.

Shimabayashi asked for the help of other lawyers through the Japan Young Lawyers Association, a large liberal association of lawyers in Japan, to which he belonged. Matsunami succeeded in gaining the support of local lawyers, not only those with leftist or liberal tenets but also those with conservative beliefs. Among these was Kinosuke Shoriki (1904-1980), a respected and influential local lawyer whose uncle, Matsutaro Shoriki (1885-1969), was the president of Yomiuri Shinbun, a conservative national newspaper with the largest circulation in Japan. This connection would prove helpful for winning the lawsuit because it brought on board conservative and respected persons, such as Kinosuke Shoriki, to counterbalance the largely antigovernment and leftist activist leanings of the other members.

On 9 March 1968, 14 victims and 14 family members of deceased victims filed a suit against Mitsui, demanding 61 million yen for pain and suffering. This was the first group of representatives of patients or the bereaved from polluted towns. If this court

${ }^{23}$ See the introduction of the present study. Yokkaichi pollution disease patients followed in September 1967. Finally, after the Itai-itai disease case, Minamata disease victims filed a suit again Chisso Cooperation, the source of pollution, in June 1969

${ }^{24}$ Matsunami is the author of a comprehensive book on Itaiitai disease (Matsunami 2010; see also Note 4). Matsunami and Shimabayshi were still in their thirties and had only 1 or $2 \mathrm{yr}$ of experience as lawyers at the time. Shimabayshi was born in Fuchu-machi in 1933 and happened to visit Toyama to help a friend from Tokyo, and he started to work as lawyer there. While staying at his parents' house in Fuchu-machi, he met with Dr. Hagino and leaders of the Itai-itai Disease Residents' Association and learned the details of the disease and the resident movement. Matsunami was born in Himi, in Toyama Prefecture, in 1930. He started to work as lawyer at Takaoka City in Toyama prefecture, near his hometown and not far from Toyama City, $30 \mathrm{~min}$ by train. In 1967, he listened to a lecture by a lawyer who had helped the second Minamata disease victims to file a suit. This lawyer suggested that he study Itaiitai disease in Toyama. After seeing in a local newspaper an announcement for a scheduled meeting discussing the lawsuit, organized by Shimabayashi and the Residents' Association, Matsunami went to the meeting, where he met Shimabayashi for the first time. Matsunami decided to help Shimabayashi with a lawsuit against Mitsui (Matsunami 2010, p. 185-188) fight went well, other victims would follow suit. In all, 236 lawyers, mostly young and inexperienced, but passionate and hard working, were involved in the suit. A group of 20 worked on the suit full-time and attended every session of the court; Shoriki became the head of this group of lawyers. One of these lawyers, Chuko Kondo, moved to Toyama from Tokyo and set up his permanent office in front of Toyama station, which became a center for the court fight. Some lawyers, including Shimabayashi, followed him and moved to Toyama. These moves helped to gain local support.

The suit was one of the largest pollution lawsuits in the history of Japan. Mitsui, one of the largest monopoly capital groups in Japan, employed the most prestigious lawyers. They even once tried to hire Kinosuke Shoriki to work on their side. When Shoriki declined, Mitsui asked him not to engage in the suit (Matsunami 2010, p. 213-214).

After 36 pleadings and 4 on-site verifications of the mine, the plaintiffs of the Itai-itai disease won their first case in June 1971. In the lawsuit, in favor of the plaintiff, 4 experts (3 university professors and Dr. Hagino) attested to the facts. The 4 experts were Noboru Hagino and Jun Kobayashi, 2 of the main discoverers of the cause of the disease, as well as Arinobu Ishizaki, a professor of the school of medicine at Kanazawa University, and Saburo Fukai, a geologist and a professor of the Toyama University. Only the director of the Kamioka mine hospital testified for Mitsui as an expert.

The court decided that a causal relationship existed between the disease and the liquid wastes of the Kamioka mine based on the epidemiological evidence $\mathrm{e}^{\mathbf{2 5}}$. This was the first occasion of a judicial decision based on epidemiological evidence in Japan. In March 1970, 1 yr before the court's verdict, the Supreme Court in Japan gathered judges who had engaged in pollution-related lawsuits, and they studied the causal relationship in such lawsuits (Matsunami 2010, p. 257). They admitted that proof based on the epidemiological evidence in principle was adequate, and if an offending company was unable to disprove the plaintiff's proof, a court should decide in favor of the plaintiff $\underline{\mathbf{2 6}}$.

One must also note that, in the case of Itai-itai disease, the mining law, which permits liability without fault, was applied. Therefore, the plaintiffs did not

\footnotetext{
$\underline{25}$ In fact, even though the Jinzu River flows through the Toyama basin, the only area ridden with the disease relied on river water not only for agricultural irrigation but also for human consumption
} 
have to prove the company's fault and intent (Matsunami 2010, p. 112-113). All they had to do was to prove that the Kamioka mine discarded waste polluted with cadmium into the Jinzu River. In contrast, in the case of Minamata disease, civil law was valid, which meant that the plaintiffs had to prove that the defendant company purposely caused the damage. This made the Minamata case very difficult to win.

Mitsui appealed to a higher court, with Jugoro Takeuchi (1922-1998), a professor at the School of Medicine at Kanazawa University, testifying for Mitsui. Takeuchi had once explained the mechanism of the function of cadmium for causing Itai-itai disease. He now denied his own theory and claimed that vitamin D deficiency was the cause of the disease. His former theory was crucial for the plaintiffs' victory in the suit, and if he could persuade the judges that he had been wrong, that would be fatal blow for the victims. However, Jun-ichi Matsunami, one of 2 young lawyers who played a key role in starting the lawsuit, cross-examined Takeuchi and disproved Takeuchi's new argument (Matsunami 1998, p. 55-131) ${ }^{27}$.

We do not know why Takeuchi denied his own theory in favor of Mitsui. One possible explanation could be Mitsui's pressure and inducement. Even though Takeuchi's deficiency theory did not change the court's decision, it played a certain role in the rollback by the mining industry, as shown below $\underline{28}$. Takeuchi was one of many experts whose 'expertise' was used to maintain the status quo of the ruling system and who were rewarded with high positions in return.

The Kanazawa branch of the Nagoya High Court did not admit any further witnesses that Mitsui pro-

$\underline{\mathbf{2 6}}$ There was discussion on this matter even in the Diet (Japanese parliament) in 1970. See the 63rd Diet minutes of the industrial pollution prevention special committee on 1 April (http://kokkai.ndl.go.jp/SENTAKU/syugiin/063/ 0620/06304010620006c.html) and the 64th Diet minutes of the legal committee on 8 December (http://kokkai.ndl.go. jp/SENTAKU/syugiin/064/0080/06412080080004c.html)

${ }^{27}$ Matsunami played an important role in various pollutionrelated lawsuits, including the subacute myelo-opticoneuropathy (SMON, a drug-induced disease) lawsuit and the Minamata disease (methyl mercury poisoning) lawsuit, until his retirement in 2001

$\underline{28}$ The Itai-itai disease suit did not seem to cause any damage to Takeuchi's career. In 1974, he became a professor at the Tokyo Medical and Dental University, a prestigious national medical university in Tokyo and later became the director of the University's hospital. He was even elected to president of the Japanese Society of Internal Medicine, one of the oldest and most prestigious medical societies. Jugoro Takeuchi was born in Chiba prefecture. He graduated from the medical school of Tokyo Imperial University in 1944

${ }^{29}$ There were 6 other lawsuits posed, and after only 12 pleadings, it dismissed the appeal on 9 August 1972. The case ended in favor of the plaintiffs. Mitsui did not appeal further. The court's final decision was that Itai-itai disease was caused by cadmium discarded by the Kamioka mine and that Mitsui was responsible for compensating the victims for all of the damages and for remediation of the contaminated soil (Matsunami 2010, p. 299-302).

By the morning of 10 August, the day after the court's decision, negotiations between Itai-itai disease victims and the company had started in Mitsui's headquarters in Tokyo. After an $11 \mathrm{~h}$ confrontation, the company admitted that the disease was caused by cadmium and other heavy metals discarded by the Kamioka mine, and thereafter pledged to refrain from disputing the court's judgment. Mitsui also admitted its responsibility in other Itai-itai lawsuits of other groups of patients ${ }^{29}$. The company agreed to not only to pay all of the plaintiffs of the litigating groups but also to compensate all of the sufferers of the disease, including those who were under medical observation and suspected of having the same disease. Mitsui also agreed to compensate for all of the agricultural damage and to restore the polluted soil (Matsunami 2010, p. 303).

One of the most important victories was the Pollution Control Agreement (Isono 1999), concluded between Mitsui and the victim's group. Under the terms of the agreement, the victim's group, the Itai-itai Disease Residents' Association, had the right to enter and inspect the mines and factories, together with experts, at the company's expense at any time and whenever the association considered it necessary. The company was obliged to release any data on pollution at the request of the association. The company was also obliged to do its best to fulfill the Residents' Association's requirements to improve its facilities to prevent further pollution.

Soon after the Itai-itai Disease Residents' Association was organized in 1966, the association went to the Kamioka mine to demand inspections, but the representatives of the association were always sent away at the main gate of the mine (Matsunami 2010, p. 168 \& 171-172). The first inspection was not conducted until November 1968, when ordered by the court. Even then, the association representatives and their experts were not able to complete their inspection of the mine due to the uncooperative attitude of the company (Matsunami 2010, p. 228-233). Therefore, the right to enter and inspect the factory was one of the most important victories resulting from the lawsuit. 


\section{THE ROLE OF EXPERTS IN THE ROLLBACK BY THE MINING INDUSTRY}

Around 1975, the mining industry was taking action to counteract citizens' movements against the industry. The backlash started with an article, written by Takaya Kodama (1937-1975), a rising young journalist, who questioned whether Itai-itai disease was a pollution-related disease and who was critical of Noboru Hagino, one of the main discoverers of the cause of the disease (Kodama 1975). Kodama criticized the cadmium theory, based on Takeuchi's vitamin D deficiency theory, which had been refuted as a cause in the Itai-itai disease suit in the high court. He even claimed that Itai-itai disease was a kind of iatrogenic disease, caused by excess administration of vitamin D by physicians.

Kodama died of cancer in May of the same year, at the age of $38^{30}$. However, the Japan Mining Industry Association distributed the article in many places and even translated it into English for overseas readers (Matsunami 2010, p. 315). Some parliament members from the ruling Liberal Democratic Party questioned the validity of the Ministry of Health and Welfare's announcement on the cause of Itai-itai disease.

The Environmental Agency, established in 1971 as a government agency, started a research program on Itai-itai disease and cadmium poisoning in 1974. After questioning in the House of Representatives, the Lower House of Japan, the agency reorganized the research group, with one of its aims being the reexamination of the cause of Itai-itai disease. The majority of the researchers of the group doubted that cadmium was the cause. Itsuzo Shigematsu, an authority on public health, was the head of the group He had introduced epidemiological research from the United States after World War II. Shigematsu, himself, was in a neutral position regarding the cause of Itai-itai disease, but the research group continued to publish reports with ambiguous and inconclusive results and, in the end, lost its credibility, even among other researchers (Matsunami 2010, p. 318-319 \& $324-336)^{31}$.

Itsuzo Shigematsu was born in Osaka in 1917. He graduated from the Medical School of Tokyo Imper-

${ }^{30}$ Takaya Kodama was born in Ashiya, Hyogo prefecture, not far from Osaka. He graduated from Waseda University. In 1974, he was noticed because of an investigative report on Kakuei Tanaka, the Prime Minister of Japan. He died of cancer on 22 May 1975 (Sakagami 2003). Sakagami, who wrote Kodama's biography, sees Kodama's article on Itaiitai disease as the only negative thing in his writing career ial University in 1941. He studied public hygiene at the Harvard School of Public Health with Michio Hashimoto and received a Master's degree in Public Health in 1955. It is interesting to compare the paths of the 2 Japanese students who finished the Harvard course in 1955. Hashimo, as an administrative official, played an important role in the early stages of anti-pollution and environmental measures for the Japanese government. Shigematsu, in contrast, directly or indirectly supported the position of offending companies and the apathetic government and thus delayed anti-pollution measures. He had chaired many governmental research committees on pollution-related or drug-induced diseases as an authority on epidemiology and seems to have played a key role in the presentation of inconclusive results, giving negative conclusions on the causes of the diseases. These negative roles did not seem to damage his career. On the contrary, he received every possible merit and honor $\frac{32}{}$. He achieved high standing in exchange for allowing his 'expertise' to be used for the maintenance of the status quo of the ruling system.

The difference between Hashimoto and Shigematsu can be explained as follows. In the academic world, it is potentially much more damaging for a researcher's reputation to advance a hypothesis which is later found to be wrong, than to advance no hypothesis at all. It is therefore in an academic researcher's own best interest to remain silent (or at least neutral) on a topic until he has obtained conclusive results to confirm his hypothesis. This 'wait-and-see' attitude would be praised, or at least accepted, in the academic world as the mark of a cautious researcher. However, this approach often causes trouble when tackling technology-related social problems because of the delays in solving such problems $\underline{33}$.

Nozumu Matsubara, a researcher of social statistics, once analyzed this damaging 'wait-and-see' atti-

\footnotetext{
31 A TV documentary program (title translated from Japanese as 'A gray zone after 30 yr: environmental pollution and the state of this country') criticized the activity of Shigematsu's research group on Itai-itai disease to disprove the results of a court decision $30 \mathrm{yr}$ before and received the Japan Congress of Journalists' Prize for 1999. This TV program was broadcast in January 1999

32 Shigematsu became professor of the medical school of Kanazawa University, the head of the Department of Epidemiology at the National Institute of Public Health in Japan, and chairman of the Radiation Effects Research Foundation, a research foundation that studies the effects of radiation on the survivors of the atomic bombings in Hiroshima and Nagasaki. He received the Sievert Prize for his work on radio-epidemiology
} 
tude in terms of statistics: Type I and Type II errors (Matsubara 2002, p. 196-200). A Type I error, also known as a false positive, takes negative things as positive, so one does what one should not do. A Type II error, also known a false negative, takes positive things as negative, so one does not do what one should do. In pollution problems, it is often the case that administrators make Type II errors, and experts promote this kind of error. Shigematsu always tried his best not to make Type I errors, ignoring the dangers of making Type II errors as an academic researcher. In contrast, Hashimoto had realized the danger of fear of making Type II errors and, as an administrator, he took a different approach to pollution-related disease to that of scientists (Hashimoto 1988, p. 136).

\section{A POLLUTION PREVENTION PROGRAM AFTER THE TRIAL: COLLABORATION OF EXPERTS AND CITIZENS}

On 16 November 1972, a group that included representatives of the victims' group, lawyers, and scientists inspected the Kamioka mine for the first time under the Pollution Control Agreement. Although the company's employees were more cooperative than before ${ }^{34}$, some tension remained between the victims and the company. The second annual inspection, from 6 to 8 August of the next year, was carried out more systematically. The inspection group made a list of survey items for each facility in the mine and demanded that the company prepare the necessary data beforehand. The group was divided into 5 subgroups, each in charge of inspection of a certain part in the mine. This second inspection became the prototype for later annual inspections (Matsunami 2010, p. $344-346)^{\frac{35}{3}}$.

Initially, for several years, constant antagonism existed between the Residents' Association and the company. Each year, the association carried out a full inspection of the mine, always in a strained atmosphere. The company broke its promise to improve its facilities more than once.

It must also be noted that local residents from polluted areas and environmentally conscious people

\footnotetext{
${ }^{33}$ Shigematsu chaired research committees on subacute myelo-optico-neuropathy (a drug-induced disease in the 1960s in Japan), Kawasaki disease, Itai-itai disease, and Minamata disease. For the criticism of Shigematsu on Minamata disease, see Tsuda (2004, p. 174-181)

${ }^{34}$ Yomiuri Shinbun, November 1972, Toyama edition, p. 12-13; Yoyama Shinbun, November 1972, p. 15
}

from all over Japan with various backgrounds, including researchers, university professors, schoolteachers, and students, participated in the inspections ${ }^{36}$. Based on the Pollution Control Agreement, a full inspection of the mine has been conducted every year since 1972. The present author participated in the 28th annual inspection of the mine in August 1999. By 2011, when the 40th annual inspection was held, the number of residents who had participated totaled 6000 and that of experts totaled 2000 since their inception (Hata 1998, p. 2, 2011) ${ }^{37}$. Mitsui paid 280 million yen for residential inspections and additional research by outside experts from 1972 to 2010. The company has also invested 21.3 billion yen for pollution preventive measures based on the advice by experts of the Residents' Association in the same years (Hata 2011).

From 1974 to 1978 , at the request of the Itai-itai Disease Residents' Association, a research project on the mine and the river was carried out with the cooperation of many universities in Japan, and the project produced comprehensive reports on reducing pollu$\operatorname{tion}^{38}$. The reports proposed some measures for Mitsui's self-management to prevent pollution, and the company started to issue an annual report on Kamioka mine's preventive measures taken each year against mining pollution.

After an annual residential inspection of the mine, a meeting between the representatives of the company and participants of the inspection is held, during which the residents ask questions and demand various measures to prevent further pollution. It is

\footnotetext{
${ }^{35}$ The annual inspection group is now divided into 7 subgroups. In August 2010, the 39th annual inspection was held with $\sim 110$ participants in the 7 subgroups, including, for the first time, 4 officials from Toyama prefecture. Kitanihon Broadcasting (KNB), a local broadcasting network in Toyama prefecture, reported the news of the visit on 10 August 2010

$\underline{36}$ According to the Pollution Protection Agreement, those whom the Residents' Association considers to be necessary can participate in the inspection, and outside participants, including researchers and ordinary citizens, belong to this category

${ }^{37}$ According to Akio Hata, who has been studying environmental problems in the Kamioka mine for a long time and has participated in various inspections of the mine from earlier periods, by 1998, the total number of residents who had participated totaled over 5000, and the number of experts added up to 1700 (Hata 1998, p. 2), and by 2010, the former reached 6000 (Hata 2011). Hata (2011) mentioned that the number of 'experts' by 2011 was 1000, but this number did not include lawyers. If the number of lawyers, who participated in the inspections, is added to that of experts, their number would reach 2000 by 2011 (A. Hata pers. comm.)
} 
said that in earlier days, the meeting was held under a tense atmosphere and always lasted almost until midnight. However, after a few years, the atmosphere of the post-inspection meeting became more friendly and sympathetic, and a constructive relationship with the company was formed.

The attitude of the company has gradually changed, for a number of reasons. For one, the experts of the Residents' Association, who were lawyers, university professors, and researchers in public institutions, cooperated with residents in the polluted areas and gained more expertise in pollution control than was possessed by the company's own mining engineers, thereby giving appropriate advice on improving the facilities. For example, during an additional inspection ${ }^{39}$ in 1977, the experts and members of the Residents' Association traced the cadmium pollution source from the zinc smelting plant to the underground drains. These continuous efforts of outside experts helped the residents gain the trust of the company.

The second factor affecting the change in the company's attitude toward inspections was the change in Japanese society itself. During the 1980s and especially the 1990s, people became more environmentally conscious. Companies that were not 'green' could not survive: environmental consciousness appealed to the public $\underline{\mathbf{4 0}}$ and could even be profitable for companies. The Kamioka mine was one of the few mines in Japan that was sufficiently large and supported by sufficient wealth to continue its operations until recently. Only in June 2001 did the mine finally

${ }^{38}$ The following 5 groups were organized in the project: (1) On the effluent from the Kamioka mine and refinery (Kyoto University)

(2) On the smoke emissions from the Kamioka refinery (Nagoya University)

(3) On the cadmium balance of the Kamioka refinery (University of Tokyo)

(4) On the sedimentation and outflow of heavy metals into the Junzu River (Toyama University)

(5) On the structural stability of the tailing dams at the Kamioka mine (Kanazawa University)

For the outline of the project, see Yoshida et al. (1999, p. 219).

Sometimes, thanks to the inspection by these experts, unknown pollution sources were identified, and appropriate countermeasures were proposed (Kurachi et al. 1979, p. 246-251)

${ }^{39}$ Besides the annual inspection, $\sim 10$ additional inspections on specific themes, like drainage, ventilation, pits, abandoned mines, and planting, are held each year (Hata 2011)

${ }^{40}$ 'Environment' is always one of the most important key words in the message from the heads of the company on the internet site of the Mitsui Mining \& Smelting Co. (www.mitsui-kinzoku.co.jp/en/gaiyo/g_message.html) close. Today, the company continues to refine and smelt imported ores from overseas mines, using the remaining facilities at Kamioka.

The $40 \mathrm{yr}$ of continuous inspections resulted not only in greatly reduced pollution outflow and improved mining facilities but also in the development of an unprecedented cooperative relationship between victims and the company. The total amount of cadmium discarded decreased from $35 \mathrm{~kg} \mathrm{mo}^{-1}$ in 1972 to $5 \mathrm{~kg} \mathrm{mo}^{-1}$ in 1997 and to $3.8 \mathrm{~kg} \mathrm{mo}^{-1}$ in 2010 , and the mean concentration of cadmium in the effluent from the mine had fallen from $9 \mathrm{ppb}$ in 1972 to $1.5 \mathrm{ppb}$ in 1996 and $1.2 \mathrm{ppb}$ in 2010. Improved dust collection reduced the total amount of cadmium discharged in smoke from $>5 \mathrm{~kg} \mathrm{mo}^{-1}$ in 1972 to $0.4 \mathrm{~kg}$ $\mathrm{mo}^{-1}$ in 1997 and $0.17 \mathrm{~kg} \mathrm{mo}^{-1}$ in 2010 (Hata 1998, p. 3, 2011). To prevent further pollution of the once polluted but now restored agricultural land, the mean concentration of cadmium was limited to $0.1 \mathrm{ppb}$, the background level. This goal was finally attained in 1996 and resulted in almost negligible cadmium outflow (Hata 1998, p. 7).

\section{CONCLUSIONS}

The present study describes the long and tortuous path by which Itai-itai disease became recognized. Second, it discusses how Itai-itai victims, concerned residents, and their supporters, such as lawyers and experts, fought a difficult struggle to receive compensation. Third, and most importantly, this struggle resulted in a comprehensive agreement between victims, concerned residents, and the polluting company, allowing concerned residents to participate in decision making and pollution prevention and thus offering a long-term solution to industrial pollution. The experience itself is valuable because it exemplifies a rare case of successful pollution control in Japan.

The Itai-itai disease case also offers good materials for analysis of the role of experts in addressing technology-related social problems, such as pollution control.

The present case study can contribute to the understanding of the nature of expertise. Epstein's (1995) study analyzed 'lay experts' on AIDS, who were themselves potential patients, friends, or family and who devoted much energy to understanding the disease. In the case of Itai-itai disease, some lawyers, such as Jun-ichi Matsunami, each became a kind of 'lay expert', who (while not a physician or scientist) gained more knowledge on the disease and pollution than experts on the company's side. These lawyers 
became 'nonscientist-but-nonetheless-knowledgeable participants' in the process (Evans \& Collins 2008, p. 611) $\underline{41}$.

The present study has also shown the significance of combining differing expertise. The cooperation between Noboru Hagino, a local physician, Kin-ichi Yoshioka, an agronomist, and Jun Kobayashi, an analytical chemist, helped to determine the cause of the disease.

However, there were also experts, such as Jugoro Takeuchi and Itsuzo Shigematsu, who directly or indirectly supported the position of the offending companies and the apathetic government and thus delayed anti-pollution measures. As Evans \& Collins noted, these individuals spoke not just as experts but also as political agents (Evans \& Collins 2008, p. 612). In the case of Shigematsu, his attitude can be explained by a certain aspect of the academic world, as shown in the section 'The role of experts'. His 'waitand-see' attitude would be praised, or at least accepted, in the academic world as the mark of a cautious researcher, but in the real world, it caused much damage. Following Matsubara (2002, p. 196200), this damaging 'wait-and-see' attitude can be analyzed in the terms of statistics, i.e. Type I and Type II errors.

The case of Hashimoto, then the head of the pollution department of the Ministry of Health and Welfare, is also important. Hashimoto insisted, as an administrator, that the public administration should act based on available scientific evidence but should not wait for conclusive scientific proof, to avoid a belated decision (Hashimoto 1988, p. 136). This is obviously the first major instance of the precautionary principle in Japan.

The case of Itai-itai disease is a good example of public participation problems. The public participation in the annual inspections of the mine played a significant role in the reduction of cadmium concentrations in the Junzu River to a safe level $\underline{42}$. As shown in the present paper, this public participation was realized largely thanks to the Pollution Protection Agreement, which was concluded after the lawsuit. Such an agreement was significant, but is the only example of its kind in Japan. Therefore, one can learn a lot from this unique case of Itai-itai disease.

\footnotetext{
41 On 'lay experts', see also Brown (1992), Callon (1999) and Callon et al. (2001)

${ }^{42}$ Itai-itai disease is not a thing of the past, however. New patients with Itai-itai disease continue to be found. After exposure to cadmium in their youth, the disease develops as patients get older (see Fujikawa 2005, Aoshima 2004)
}

\section{LITERATURE CITED}

Aoshima K (2004) Jinzu-gawa ryuiki jumin no kadomiumu bakuro to jin-shogai: genjo to korekara. [in Japanese; Cadmium exposure and kidney disorders of Jinzu River residents: present and future]. Itai-itai byo seminar koenshu [Proc Itai-itai Dis] 22:6-23

Brown P (1992) Popular epidemiology and toxic waste contamination: lay and professional ways of knowing. J Health Soc Behav 33:267-281

Callon M (1999) The role of lay people in the production and dissemination of knowledge. Sci Technol Soc 4:81-94

Callon M, Lascoumes P, Barth, Y (2001) Agir dans un monde incertain. Éditions du Seuil, Paris

Daintith J (ed) (2008) Oxford dictionary of chemistry, 6th edn. Oxford University Press, Oxford

Dehn U (1995) Tanaka Shozo: ein Vorkämpfer für Menschenrechte und Umweltschutz. Deutsche Gesellschaft für Natur und Völkerkunde Ostasiens (OAG), Tokyo

Epstein S (1995) The construction of lay expertise: AIDS activism and the forging of credibility in the reform of clinical trials. Sci Technol Human Values 20:408-437

Evans R, Collins H (2008) Expertise: from attribute to attribution and back again? In: Hackett EJ, Amsterdamska O, Lynch M, Wajcman J (eds) The handbook of science and technology studies, 3rd edn. MIT Press, Cambridge, MA, p 609-630

Fujikawa K (2005) Kogai higai houchi no sho-yoin [in Japanese; Several factors leading to the neglect of pollution related disease]. Kankyo-shakai-gaku Kenkyu [J Environ Sociol] 11:103-116. http://ci.nii.ac.jp/naid/110008726923

Hashimoto M (1988) Shi-shi kankyo gyosei. [in Japanese; Personal reminiscence on Japanese environmental administration]. Asahi Shinbun Sha, Tokyo

Hata A (1998) Itai-itai byo saiban go no jumin-sanka ni yoru hassei-gen-kisei to kigyu-joho-kokai no yakuwari [in Japanese; The control of a pollution source by the participation of local residents and the role of access to the involved company's information after the Itai itai disease lawsuit]. Mizu-shigen Kankyo Kenkyu [J Water Environ Issues] 11:1-10 doi:10.6012/jwei.1998.1

Hata A (2011) Kamioka kozan no haisui taisaku no totatsuten to kongo no kadai [in Japanese; Accomplishment and further problems in the drainage measures in the Kamioka mine]. Proceedings of the Symposium to Commemorate the 40th Annual Inspection of the Kamioka Mine, Toyama, Japan, 6 Aug 2011, p 5-9

Hatta S (1983) Shi no kawa to tatakau: itai-itai byo wo otte [in Japanese; Fighting against death river: following Itai itai disease] (ser. Kaisei-sha bunko). Kaisei-sha, Tokyo

Isono Y (1999) Itai-itai disease and the Pollution Control Agreement. In: Koji N, Mitsuo K, Minoru K (eds) Advances in the prevention of environmental cadmium pollution and countermeasures. Proc Int Conf Itai-itai Dis, Environmental Cadmium Pollution and Countermeasures, Toyama, Japan, 13-16 May 1998. Eiko Laboratory, Kanazawa, p 213-214

Itai-itai byo sosho bengo-dan [the defense counsel of the Itaiitai disease suit] (1972) Itai-itai byo saibain [in Japanese; Itai-itai disease lawsuit], Vol 3. Sogo Tosho, Tokyo

Iwamoto A (1999) Restoration of Cd-polluted paddy fields in the Jinzu River Basin. In: Koji N, Mitsuo K, Minoru K (eds) Advances in the prevention of environmental cadmium pollution and countermeasures. Proc Int Conf Itaiitai Dis, Environmental Cadmium Pollution and Counter- 
measures, Toyama, Japan, 13-16 May 1998. Eiko Laboratory, Kanazawa, p 179-183

Kaji M (2005) Itai-itai byo mondai kaiketsu nimiru senmonka to shimin no yakuwari [in Japanese; The role of expert and citizen participation in pollution control: in the case of Itai-itai disease]. In: Fujigaki Y (ed) Kagakugijutsu-shakai-ron no giho [Case analysis and theoretical concepts for science and technology studies]. University of Tokyo Press, Tokyo, p 21-42

Kaji M (2009) Shakai ni okeru senmonka no yakuwari: itaiitai byo no byoin wo meguru giron kara. [in Japanese; The role of experts in society: the debates on the cause of Itai-itai disease]. In: Kaji M, Saijo M, Nohara K (eds) Kagaku-gijutsu komyunikeishon nyumon [An introduction to science and technology communication]. Baifukann, Tokyo, p 73-86

Kankyo-cho (Environmental Agency, Japan) (1973) Showa 48 nen ban Kankyo Haku-sho. [in Japanese: White Paper on the environment in Japan for 1973]. Ookura sho Insatsu-Kyoku, Tokyo

Kodama T (1975) Itai-itai byo wa maboroshi no kogai-byo $\mathrm{ka}$ ? [Is Itai-itai disease a mere phantom?]. Bungei-shunju 53:312-338

Kurachi M, Tonegawa H, Hata A (1979) Mitsui Shihon to Itai-itai byou [in Japanese; Mitsui capital and Itai-itai disease]. Ootsuki-Shoten, Tokyo

Kurachi M (1999) General research into cadmium poisoning prevention in the Jinzu River Basin and the worldwide significance of pollution-free mining. In: Koji N, Mitsuo K, Minoru K (eds) Advances in the prevention of environmental cadmium pollution and counter measures. Proc Int Conf Itai-itai Dis, Environmental Cadmium Pollution and Counter measures, Toyama, Japan, 13-16 May 1998. Eiko Laboratory, Kanazawa, p 149-154

Matsubara N (2002) Kankyo-gaku ni okeru data no jubunsei to ishi-kettei-handan [in Japanese; Adequacy of data

Editorial responsibility: Tomiko Yomaguchi, Tokyo, Japan; Karen Cronin, Wellington, New Zealand; and

Darryl Macer, Bangkok, Thailand and decision-making judgment in environmental studies]. In: Ishi H (ed) Kankyo-gaku no giho [Social methods of environmental studies]. University of Tokyo Press, Tokyo, p 167-214

Matsunami J (1998) Aru Hantai Jinmon. [in Japanese; Cross-examinations]. Nihon Hyoron, Tokyo

Matsunami J (2010) Kadomiumu higai hyakunen: Kaiko to tenbo. [in Japanese; A hundred years of cadmium poisoning: recollection and prospects]. Katsura Shobo, Toyama

Nicaud P, Lafitte A, Gros A (1942) Les troubles de l'intoxication chronique par le cadmium. Arch Mal Prof Med Trav Secur Soc 4:192-202

Sakagami R (2003) Munen wa chikara Densetsu no ruporaita Kodama Takaya no 38 nen [in Japanese; Shame is power: Takaya Kodama, legendary writer's 38 years]. Joho-Center-Shoppankyoku, Tokyo

Sismondo S (2010) An introduction to science and technology studies, 2nd edn. Wiley-Blackwell, Chichester

Tsuda T (2004) Igaku-sha wa Kogai-jiken de nani wo shitekita-noka? [in Japanese; What did medical researchers do in pollution cases?]. Iwanami Shoten, Tokyo

Yamada Y (1951) Nihon no aen-kogyu ni tsuite [in Japanese; On lead mining and metallurgy in Japan]. Nihon Kogyo Kaishi [J Mining Inst Jpn] 67:46-51

Yoshida F, Hata A, Tonegawa H (1999) Itai-Itai disease and the countermeasures against cadmium pollution by the Kamioka mine. Environ Econ Policy Stud 2:215-229

Yoshioka K (1961) Jinzu-gawa suikei kogai kenkyu hokokusho [in Japanese; Report on mining pollution study of the Jinzu River and its tributaries]. Kurashiki

Yoshioka K (1964) Itai-itai byo to kogai tono kanrensei ni tsuite no eikigaku teki kenkyu [in Japanese; Epidemiological study on the relationship between Itai itai disease and mining]. Yomaguchi Igaku [Yamaguchi Med J] 3: $146-170$

Yui M (1984) Tanaka Shozo. Iwanami Shoten, Tokyo

Submitted: June 30, 2011; Accepted: January 29, 2011

Proofs received from author(s): June 24, 2012 